\title{
Kształcenie zawodowe w Polsce \\ - przemiany, organizacja, efekty
}

DOI: $10.47050 / 65591814.66-101$

Elżbieta Drogosz-Zabłocka, Jędrzej Stasiowski

W rozdziale przedstawiono przemiany zachodzące w kształceniu zawodowym w Polsce w okresie od zakończenia II wojny światowej do chwili obecnej. Dzięki ukazaniu warunków politycznych, kulturowych i gospodarczych, w jakich funkcjonowały szkoły zawodowe, nakreślono charakter wprowadzanych reform, w wyniku których kształcenie zawodowe zmieniało w czasie swoją organizację, formę, funkcje, treści nauczania, a w konsekwencji efekty kształcenia. Pokazano także, jak zmieniało się zaangażowanie pracodawców w proces kształcenia zawodowego, a szczególnie w organizację i realizację praktycznej nauki zawodu. W końcowej części rozdziału podjęto próbę określenia, czym jest obecnie wykształcenie zawodowe.

\section{Słowa kluczowe:}

szkoła kształcąca zawodowo

reforma kształcenia zawodowego

praktyczna nauka zawodu

kwalifikacja

system dualny

wykształcenie zawodowe 


\section{Vocational education in Poland \\ - changes, organization, effects}

DOI: $10.47050 / 65591814.66-101$

Elżbieta Drogosz-Zabłocka, Jędrzej Stasiowski

Article shows the changes that occurred in vocational education in Poland, starting from the end of World War II. The shape of conducted reforms that influenced organization, form, function and the curriculum in the vocational education within time is pictured throughout the analysis of different political, cultural and economic conditions. It is also shown how the influence of employers on the process of vocational education has changed, with focus on organization and realization of practical vocational training. The last paragraphs of the article try to define current vocational education.

\section{Keywords:}

vocational school

reform of vocational education

practical training

qualification

dual system

vocational education

vocational background 


\section{Przemiany w kształceniu zawodowym}

W ostatnim stuleciu dwa procesy dotyczące funkcjonowania edukacji zasługują na uwagę: jej demokratyzacja i upowszechnianie. Wiązały się one z rozszerzeniem uprawnień i uczestnictwa w edukacji oraz $z$ wydłużeniem obowiązku szkolnego i obowiązku nauki. W następstwie tych wyzwań poszczególne kraje dążyły do tworzenia jednolitych systemów szkolnych zapewniających powszechność i dostępność szkół wszystkich typów i poziomów. Systemy szkolne powstawały w różnych warunkach politycznych, kulturowych i gospodarczych, co sprawiało, że różniły się znacznie od siebie (jest tak do teraz), w pewnym zakresie jednak pozostawały ze sobą zbieżne. Dotyczyło to dostępności i powszechności edukacji, które miały zostać zapewnione przez: bezpłatność nauczania, odpowiednią sieć szkolną (m.in. położenie szkoły blisko miejsca zamieszkania, powstanie obwodów szkolnych), system stypendialny (dostępność edukacji dla dzieci z rodzin ubogich) oraz działania na rzecz zapobiegania wykluczeniu z systemu szkolnego. Jednolity system szkolny (rozumiany m.in. jako powszechna dostępność wszystkich typów i szczebli szkół) charakteryzował się późnym odłączeniem szkolnictwa podstawowego od ponadpodstawowego, drożnością poziomą i pionową, a także możliwością kontynuowania nauki w systemie pozaszkolnym, gdy zostały spełnione wymagania związane z realizacją obowiązku szkolnego. Przemiany w kształceniu zawodowym, które zmieniało $w$ czasie swoją formę, funkcje i organizację oraz efekty, wpisują się w powyższe procesy.

W tym rozdziale punktem odniesienia będą szkoły zawodowe i otoczenie, w którym funkcjonowały, a także zagadnienia treści nauczania przedmiotów zawodowych i praktycznej nauki zawodu, uzyskiwane kwalifikacje i dyplomy. Pokazanie przemian kształcenia zawodowego $w$ tej perspektywie daje nam nie tylko obraz reform i pojawiających się problemów, ale także unaocznia aktualność niektórych z nich, mimo radykalnych zmian w czasie zarówno $w$ samym systemie edukacji, jak i w otoczeniu szkoły. Zachowując spójność czasową z pozostałymi rozdziałami w tym opracowaniu, które w zasadniczej części dotyczą systemu edukacji funkcjonującego do roku szkolnego 2017/2018, w niniejszym rozdziale koncentrujemy się na przemianach wprowadzanych $w$ tym okresie. O ile to możliwe i uzasadnione, sygnalizujemy także zmiany, które zostały wprowadzone w drugiej połowie 2018 i w pierwszych miesiącach 2019 r. Niektóre z nich zmieniają dotychczasowe 
podstawy prawne funkcjonowania szkolnictwa zawodowego zarówno w odniesieniu do samych szkół, jak i podstaw programowych, klasyfikacji zawodów (w tym branżowych szkół I ill stopnia) i otoczenia szkół (w pewnym zakresie związanym z doradztwem zawodowym i współpracą z pracodawcami). Ponieważ reforma kształcenia zawodowego nadal jest $w$ toku, opisywane przez nas przemiany odnoszą się tylko do części wprowadzonych zmian. Opis i analiza zmian prawnych wprowadzonych w roku szkolnym 2018/2019, a przede wszystkim konsekwencje ich wprowadzenia wymagają naszym zdaniem odrębnej publikacji, poprzedzonej badaniami obejmującymi ten obszar reform, najlepiej po zamknięciu pełnego cyklu kształcenia.

\section{Reformy kształcenia zawodowego w okresie powojennym}

Ukazanie zmian w kształceniu zawodowym, a w konsekwencji uzyskiwanego tą drogą wykształcenia zawodowego, poprzedzimy opisem dłuższego niż w innych rozdziałach (analizujących czas od wejścia Polski do Unii Europejskiej) okresu przemian, sięgającego aż początków lat 50. ubiegłego stulecia. Decyzję naszą motywujemy m.in. potrzebą pokazania tych rozwiązań organizacyjnych i instytucjonalnych, które powstały $w$ tamtym czasie i przetrwały do 2016 r. Takim rozwiązaniem są m.in. zasadnicze szkoły zawodowe pozwalające na uzyskanie wykształcenia zawodowego w zakresie zawodów robotniczych.

Po Il wojnie światowej szkolnictwo zawodowe przeżywało znaczne trudności, głównie natury organizacyjnej, ale także kadrowej. Nowy ustrój polityczny i gospodarczy w swoich wieloletnich planach rozwojowych wskazywał na potrzebę zatrudnienia kilkuset tysięcy wykwalifikowanych robotników. Bezpośrednio wiązało się to z koniecznością ich przygotowania, a w rezultacie z rozwojem kształcenia zawodowego. Realizacja tego zadania wymagała rozwiązań organizacyjnych, których nie było. Pierwszym krokiem zmierzającym w kierunku usunięcia tych trudności było powołanie w 1949 r. Centralnego Urzędu Szkolenia Zawodowego (CUSZ) ${ }^{1}$ jako naczelnego organu planowania i organizowania szkolnictwa zawodowego oraz zarządzania nim. Szkoły zawodowe wyłączono z systemu oświaty i przypisano je do poszczególnych ministerstw, zgodnie z kierunkami kształcenia. CUSZ przejął też wszystkie 
kursy i szkoły zawodowe. Miał dużą swobodę działania, ponieważ posiadał oddziały terenowe we wszystkich województwach, a podstawy prawne zapewniały mu w realizacji powierzonych zadań obowiązkową pomoc centralnych urzędów i zakładów pracy (np. zagwarantowanie lokali, udostępnianie urządzeń technicznych, umożliwienie praktyk zawodowych i współpracę pedagogiczną). Do zadań CUSZ należało zarówno tworzenie nowych szkół i kursów zawodowych, jak i przygotowywanie kadr dla gospodarki, kierowanie absolwentów do pracy, opracowywanie aktów prawnych związanych z funkcjonowaniem szkół, sprawy organizacyjne oraz treści i podręczniki oferowane w kształceniu zawodowym. CUSZ był urzędem typowym dla scentralizowanej i zbiurokratyzowanej gospodarki socjalistycznej.

Drugim krokiem była uchwała Prezydium Rządu z 23 czerwca 1951 r. wprowadzająca nowy ustrój szkolnictwa zawodowego, na który składały się:

1. Zasadnicze szkoły zawodowe o dwu- a później trzyletnim cyklu nauczania, przygotowujące wykwalifikowanych robotników kilkuset specjalności, przeznaczone dla absolwentów siedmioletniej szkoły podstawowej. W szkołach zasadniczych realizowano elementarny cykl kształcenia ogólnego, teoretyczne kształcenie zawodowe i praktyczną naukę zawodu, która odbywała się głównie w zakładach przemysłu ciężkiego. Szkoła ta, zachowując swoją pierwotną nazwę, przetrwała do 2016 r., chociaż była wielokrotnie reformowana.

2. Technika, początkowo trzyletnie, później cztero- i pięcioletnie, które oferowały absolwentom siedmioletniej szkoły podstawowej teoretyczne i praktyczne przygotowanie zawodowe i możliwość zdania matury; łączyło się to z możliwością kontynuowania nauki na studiach wyższych (początkowo po zdaniu egzaminu wstępnego).

3. Szkoły przysposabiające do zawodu (SPZ), gdzie nauka trwała od kilku miesięcy do półtora roku, przeznaczone dla młodzieży, która nie ukończyła siedmioletniej szkoły podstawowej; ich zadaniem było praktyczne przygotowanie do wykonywania zawodu. Uczniowie niektórych z tych szkół korzystali z bezpłatnych internatów i wyżywienia, a także umundurowania. Były też szkoły przysposobienia rolniczego. W pewnym sensie ich współczesną kontynuacją są Hufce Pracy. 
4. Wieczorowe i korespondencyjne szkoły zawodowe zasadnicze i technika, przeznaczone dla młodzieży i dorosłych pracujących.

5. Specjalistyczne kursy kształcenia zawodowego.

W 1956 r. wprowadzono do systemu dwuletnie szkoły policealne i pomaturalne, które oferowały kształcenie odpowiadające przygotowaniu zawodowemu robotników wykwalifikowanych lub techników. Od 1958 r. umożliwiono młodocianym pracownikom w wieku od 14. do 18. roku życia naukę zawodu, przyuczenie do nowej pracy lub odbycie wstępnego stażu w zakładzie pracy². Określono także warunki ich zatrudniania i wynagradzania. Nauka w tym trybie trwała od dwóch do czterech lat i kończyła się egzaminem. Wszyscy absolwenci szkół zawodowych, a także młodociani pracownicy, którzy uzyskali kwalifikacje zawodowe, byli zobowiązani do odbycia wstępnego stażu pracy trwającego od sześciu miesięcy do dwóch lat, chyba że praca, którą wykonywali, nie wymagała kwalifikacji. Prace niewymagające kwalifikacji zawodowych były określane przez poszczególnych ministrów w porozumieniu z ministrem pracy.

W zasadzie wszystkie działania dotyczące kształcenia zawodowego były określane na szczeblu centralnym, a ich realizacja - kontrolowana. Rozwiązania te, szczególnie ustrój szkół zawodowych, przetrwały wiele lat, chociaż szkoły zawodowe podlegały licznym reformom, szczególnie programowym, co miało wpływ na uzyskiwane wykształcenie zawodowe. Lata 1948-1956 charakteryzowały się też powszechną indoktrynacją ideologiczną uczniów, co znajdowało odbicie zarówno w treściach, jak i w praktyce pedagogicznej. Nie ominęło to nawet treści zawodowych (Kwieciński 1995, s. 61).

Druga połowa lat 50. i lata 60. charakteryzowały się znacznym liczbowym wzrostem szkół, uczniów i nauczycieli. Ustawa z 15 lipca 1961 r. o systemie oświaty i wychowania ${ }^{3}$ wprowadziła ośmioletnią szkołę podstawową oraz szkoły ponadpodstawowe (już na bazie szkoły ośmioletniej) ogólnokształcące i zawodowe tych samych typów, które zostały powołane w 1951 r. Ustawa określała świecki charakter naucza- 
nia i wychowania, nie burzyła dotychczasowego ustroju szkół, tylko go rozszerzała.

Po zakończeniu obowiązkowej ośmioletniej szkoły podstawowej można było kontynuować kształcenie w zasadniczej szkole zawodowej lub w szkole średniej (liceum ogólnokształcącym, technikum zawodowym lub liceum zawodowym). Zasadnicza szkoła zawodowa kształciła kwalifikowanych robotników, pracowników i rolników ${ }^{4}$. Nauka w niej trwała dwa lub trzy lata, w zależności od kierunku kształcenia. Ustawa dawała możliwość tworzenia przyzakładowych szkół zasadniczych, które były zakładane, utrzymywane i prowadzone przez zakłady pracy, a sposoby ich finansowania określała Rada Ministrów. Minister odpowiedzialny za daną branżę wskazywał zakłady pracy, które mogły takie szkoły zakładać i prowadzić. Minister oświaty, w porozumieniu z zainteresowanymi ministrami, określał zasady organizacji i funkcjonowania tych szkół.

W 1971 r. powołano Komitet Ekspertów w celu opracowania raportu o stanie oświaty w PRL-u, pracujący pod kierunkiem prof. Jana Szczepańskiego. Zagadnienia kształcenia zawodowego zajmowały w raporcie znaczące miejsce. Zwracano w nim uwagę, że "podstawowe zadania szkoły zawodowej polegają na: wszechstronnym przygotowaniu absolwentów do pracy i życia w społeczeństwie socjalistycznym, a zwłaszcza na przygotowaniu ich do pracy w określonym zawodzie oraz zapewnieniu im wykształcenia ogólnego i zawodowego, umożliwiającego kontynuowanie nauki w szkołach lub na kursach wyższego szczebla" (Raport o stanie oświaty... 1973, s. 134). Diagnoza kształcenia zawodowego wskazywała, że realizacja tego zadania w praktyce napotyka poważne trudności. Zwracano uwagę na przeładowanie programów nauczania, brak nowoczesnych podręczników oraz na przestarzałe wyposażenie laboratoriów i warsztatów szkolnych. Wskazywano także na utrzymujące się trudności formalne w uzyskiwaniu zgody na organizowanie zajęć i wycieczek do zakładów pracy (mimo zgody zadeklarowanej w oficjalnym przekazie), a także na słabe wyniki nauczania w tych szkołach. W 1971 r. w szkołach przyzakładowych i dokształcających uczyło się 48\% uczniów zasadniczych szkół zawodowych. Podstawową wadą tych rozwiązań było wąskospecjalistyczne kształcenie odpowiadające na 
zapotrzebowanie danego zakładu, niedostateczna realizacja obowiązujących programów nauczania i brak odpowiednio przygotowanej kadry. W raporcie podkreślano, że absolwentom szkół zawodowych brakuje zarówno wiedzy ogólnokształcącej, jak i umiejętności praktycznych. Zaznaczano ponadto, że ich wiedza zawodowa jest przestarzała i że nie posiadają oni doświadczenia w wykonywaniu zadań zawodowych, mają braki w przygotowaniu w zakresie zarówno organizacji stanowiska pracy, jak i umiejętności współpracy z innymi pracownikami i z kadrą kierowniczą. Problemem były wysoka drugoroczność i odsiew uczniów. Można na tej podstawie stwierdzić, że uzyskiwane wykształcenie zawodowe było niskiej jakości. Osobną trudność stanowiło słabe wykształcenie nauczycieli. Realizacja postulatu, aby w szkołach podstawowych i średnich uczyli nauczyciele z wykształceniem akademickim (lub wyższym zawodowym), wymagałaby w tym czasie skierowania na studia ponad 200 tys. osób (Raport o stanie oświaty... 1973, s. 174). Ponadto podnoszono kwestię nieprzygotowania pedagogicznego wśród nauczycieli zawodu i instruktorów w zakładach pracy, a wśród nauczycieli przedmiotów zawodowych - brak przygotowania praktycznego.

Raport ekspertów wskazywał na potrzebę ograniczenia dwutorowości maturalnego szkolnictwa średniego (przygotowanie do zawodu vs przygotowanie do studiów wyższych) i budowanie systemu szkolnego, który zapewnia powszechność nauczania, elastyczność oraz umożliwia upowszechnienie wykształcenia średniego. W 1973 r. sejm, wykorzystując wcześniejsze ustalenia przygotowane poza wnioskami z raportu, przyjął Uchwałę w sprawie systemu edukacji narodowej, co oznaczało wprowadzenie tzw. dziesięciolatki na wzór szkół radzieckich i wschodnioniemieckich. Reformę rozpoczęto w 1978 r., ale po Sierpniu 1980 r. odstąpiono od jej przeprowadzenia.

Sierpień '80 obnażył nieefektywność systemu kształcenia i konieczność głębokich zmian w edukacji, także zawodowej. Chociaż nie było bezrobocia, ponieważ każdy absolwent miał zapewnioną pracę, to kształcenie zawodowe, w porównaniu z ogólnokształcącym, było nadmiernie rozbudowane, wąskospecjalistyczne i nastawione na zaspokajanie potrzeb niekonkurencyjnej, centralnie sterowanej gospodarki, przede wszystkim przemysłu ciężkiego. Stało to w sprzeczności z przekształcającą się gospodarką.

Kolejne zmiany związane z przebudową całego państwa, w tym gospodarki, przyniósł koniec lat 80 . Okrągły Stół w 1989 r., w którym brali 
udział przedstawiciele środowisk oświatowych („podstolik" ds. oświaty i młodzieży), przyczynił się także do zwrócenia uwagi na problemy edukacji, także zawodowej. W podsumowaniach sięgano do postanowień z 1981 r.

\section{Przemiany po roku 1990}

System kształcenia zawodowego odziedziczony po latach socjalizmu był scentralizowany i nie odpowiadał na potrzeby powstającej gospodarki rynkowej. Najpilniejszymi problemami były zmiana programów nauczania oraz określenie sposobu finansowania kształcenia zawodowego w nowych warunkach gospodarczych. Na początku lat 90. powołano w Ministerstwie Edukacji Komisję ds. Reformy Kształcenia Zawodowego, która zaproponowała nowy model edukacji zawodowej. Przewidywał on utworzenie: szkół zasadniczych kształcących w cyklu trzyletnim i zapewniających przygotowanie ogólnokształcące i ogólnozawodowe, z możliwością zdawania egzaminu na tytuł czeladnika lub robotnika wykwalifikowanego; czteroletnich liceów technicznych, z możliwością zdawania matury po ich zakończeniu i kontynuowania nauki w szkołach pomaturalnych i wyższych oraz szkół pomaturalnych kształcących w cyklu od pół roku do trzech lat, z możliwością zdawania egzaminu na tytuł technika (Drogi rozwoju... 1991). Ten model nie doczekał się jednak wdrożenia, a wielokrotnie nowelizowana, wciąż jednak jeszcze funkcjonująca ustawa o systemie oświaty z 1961 r. została zmieniona dopiero we wrześniu $1991 \mathrm{r}$. Jednym z nowych rozwiązań w tym okresie było złamanie monopolu państwa na zakładanie i prowadzenie szkół. Zaczęły powstawać zawodowe szkoły niepubliczne, szczególnie na poziomie policealnym. Osobnym problemem była kwestia kompetencji dydaktycznych nauczycieli szkół zawodowych, stanowiących ok. 1/5 wszystkich zatrudnionych w szkołach nauczycieli (najliczniejszej, po nauczycielach szkół podstawowych, grupy). Nie byli oni przygotowani do kształcenia pracowników dla potrzeb gospodarki rynkowej, a efekty takiego kształcenia powinny uwzględniać inne niż dotychczas kwalifikacje absolwentów, np. szersze podstawy ogólnokształcące i większą elastyczność uzyskanych kwalifikacji umożliwiających adaptację do zmieniających się warunków rynkowych (Wiatrowski 1999). Problem ten pozostaje ciągle aktualny (por. kolejny rozdział).

W roku szkolnym 1990/1991 naukę w szkołach kształcących zawodowo kontynuowało $72 \%$ absolwentów szkół podstawowych 
(46\% w ZSZ i $26 \%$ w średnich szkołach zawodowych), a uczniowie kształcący się w kierunkach technicznych stanowili 59\% wszystkich uczniów. Kształcenie zawodowe odbiegało jednak od potrzeb gospodarki rynkowej, a absolwenci tych szkół masowo nie mogli znaleźć pracy. W listopadzie 1991 r. (dane Departamentu Zatrudnienia Ministerstwa Pracy i Polityki Społecznej) absolwenci zawodowych szkół technicznych (zasadniczych i średnich) stanowili największy odsetek wśród bezrobotnych, na kolejnych miejscach byli absolwenci kierunków rolniczych i ekonomicznych. Najbardziej narażeni na pozostanie bezrobotnymi byli absolwenci zasadniczych szkół zawodowych. Wiele wysiłku włożono w przygotowanie zmian w zakresie organizowania i realizacji praktycznej nauki zawodu, co miało pomóc w zmniejszaniu bezrobocia wśród absolwentów szkół zawodowych. W 1992 r. w Rozporządzeniu dotyczącym organizowania i finansowania praktyk zawodowych i praktycznej nauki zawodu zaproponowano rozwiązania, które wychodziły naprzeciw oczekiwaniom społecznym i gospodarce. Jednak realizacja tych ustaleń napotkała liczne trudności wynikające z problemów finansowych przedsiębiorstw i braku zainteresowania $z$ ich strony kształceniem zawodowym. Nie respektowano programów nauczania, przedsiębiorstwa były coraz bardziej rozproszone, a współpraca z edukacją nie należała do ich priorytetów i często wykraczała poza możliwości finansowe. W sytuacji dotkliwego bezrobocia absolwentów szkół zawodowych podejmowano działania zmierzające do ograniczenia skutków tego zjawiska. Były to zarówno starania oświatowych władz lokalnych (inwestowanie w tańsze i oferujące dłuższy okres nauki szkolnictwo ogólnokształcące), jak i młodzieży (wybór takich ścieżek kształcenia, które przedłużały edukację i opóźniały start zawodowy). W rezultacie stopniowo realizowano strategie modyfikowania systemu edukacji, a zwłaszcza kształcenia zawodowego, tracącego swoje znaczenie na rzecz edukacji ogólnokształcącej (Andrzejczak 1999).

W drugiej połowie lat 90 . zagadnieniom kształcenia zawodowego poświęcono wiele opracowań powstających z inicjatywy Europejskiej Fundacji Kształcenia (European Training Foundation - ETF) w Turynie. W 1996 r. rozpoczęła ona realizację programu organizacji narodowych obserwatoriów kształcenia i szkolenia zawodowego w krajach Europy 
Środkowej i Wschodniej ${ }^{5}$. Zidentyfikowane przez obserwatorium problemy kształcenia i szkolenia zawodowego dotyczyły okresu bezpośrednio poprzedzającego wprowadzenie reformy edukacji i włączenia Polski do struktur Unii Europejskiej (2004 r.). W raportach podkreślano, że reforma edukacji jest przedsięwzięciem komplementarnym do bezpośrednich zadań związanych z przystąpieniem Polski do Unii Europejskiej (UE) - całość edukacji pozostaje bowiem w kompetencji krajów członkowskich. Nowelizacja polskiego prawa w obszarze edukacji miała natomiast dotyczyć obszaru uznawalności dyplomów i kwalifikacji zawodowych wszędzie tam, gdzie wymagają tego odpowiednie przepisy UE. Uznawalność kwalifikacji i ich potwierdzanie miało wpływ na uzyskiwane wykształcenie zawodowe (por. Sitek w tym opracowaniu). Oferowane wówczas programy UE w zakresie kształcenia zawodowego, np. program Leonardo da Vinci, miały posłużyć włączeniu Polski w unijne sieci współpracy i wymiany doświadczeń.

Poniższa tabela ilustruje wybrane potrzeby, problemy i wyzwania w zakresie kształcenia i szkolenia zawodowego, które zidentyfikowano w raportach z lat 1997-2002, tj. w okresie bezpośrednio poprzedzającym wprowadzenie szkół ponadgimnazjalnych 1 września 2002 r. Podobnie jak $w$ raportach, $w$ tabeli przedstawiono działania niezbędne do tworzenia spójnego systemu i związane z nimi przeszkody, stojące na drodze do ich wdrożenia. Pominięto natomiast działania szczegółowe, odnoszące się do poziomu instytucji/szkoły/placówki lub związane z realizacją krótkofalowych zamierzeń. Zidentyfikowane potrzeby odzwierciedlały problemy kształcenia zawodowego w latach poprzedzających przystąpienie Polski do Unii Europejskiej.

W Polsce zadanie organizacji narodowego obserwatorium powierzono Biuru Koordynacji Kształcenia Kadr w Fundacji Fundusz Współpracy. Powstały wówczas raporty na temat kształcenia i szkolenia zawodowego, mające służyć zarówno władzom krajowym, jak i Komisji Europejskiej oraz krajom członkowskim UE w polityce reformowania systemów kształcenia i szkolenia zawodowego oraz zewnętrznego wspierania tych zadań. Raporty zostały opracowane zgodnie z zaleceniami Europejskiej Fundacji Kształcenia, a zagadnienia w nich poruszane w znacznym stopniu uwzględniały punkt widzenia zachodnich odbiorców. Miało to jednak kapitalne znaczenie u progu naszego członkowska w UE. 
Tabela 1. Wybrane potrzeby, problemy i wyzwania

kształcenia zawodowego w latach 1997-2002

\begin{tabular}{c|c} 
Potrzeby & $\begin{array}{c}\text { Główne } \\
\text { przeszkody }\end{array}$ \\
\hline
\end{tabular}

1997

Kształcenie i szkolenie zawodowe nie znajdują właściwego miejsca w strategiach rozwoju kraju oraz reformach edukacyjnych.

Rozbieżność strukturalna między klasyfikacją zawodów szkolnych

Brak docelowej wizji systemu a klasyfikacją zawodów i specjalności występujących na rynku pracy.

kształcenia i szkolenia zawodowego, Niedoinwestowanie i niewystarczające zasoby infrastrukturalne a zwłaszcza jego części szkolnej w obszarze kształcenia i szkolenia zawodowego.

Nieefektywny i przestarzały system doskonalenia nauczycieli; braki w kształceniu nauczycieli; nieefektywne mechanizmy awansu nauczycieli.

Stworzenie systemu zapewniania jakości usług edukacyjnych

Brak zainteresowania ze strony pracodawców udziałem w reformowaniu kształcenia zawodowego i budowaniu systemu zapewniania jakości usług edukacyjnych.

Dominacja kształcenia zawodowego oferowanego przez system szkolny, co skutkuje nieelastycznymi strukturami organizacyjnymi

Metody i formy kształcenia i dydaktycznymi.

niedostosowane do różnych grup

odbiorców

Niektóre branże (np. bankowość) tworzą własne systemy dalszego

kształcenia i szkoleń, samodzielnie pokonując zdefiniowane prze-

szkody.

Poprawa współpracy środowisk gospodarczych i obszaru kształcenia i szkolenia zawodowego na poziomie krajowym

Brak sprawnego mechanizmu komunikacji różnych aktorów kształcenia zawodowego.

Brak współpracy środowisk gospodarczych z instytucjami kształcenia zawodowego.

Poprawa efektywności wykorzystania ograniczonych zasobów finansowych na kształcenie zawodowe

Niedostateczne przygotowanie kadr na poziomie lokalnym do zarządzania finansami publicznymi (od 1997 r. szkoły ponadpodstawowe otrzymują środki z budżetu państwa za pośrednictwem wojewodów lub kuratoriów oświaty lub gmin, szkoły resortowe dotowane są z budżetu właściwych ministerstw). Brak ram prawnych i instytucjonalnych do realizacji tego zadania.

Stworzenie zintegrowanego systemu poradnictwa zawodowego

Brak dobrze wykształconej kadry.

Niedostatek i zapóźnienie stosowanych metod i środków wykorzystywanych w poradnictwie.

Opracowanie systemu bieżącej i perspektywicznej koordynacji kształcenia z potrzebami gospodarki

Statystyka rynku pracy operuje zbyt dużymi agregatami, jest mało

Udoskonalenie bieżącego przepływu informacji między rynkiem pracy a kształceniem zawodowym 


\section{8}

Brak należnego miejsca dla kształcenia zawodowego w strategii rozwoju kraju i projektach reform edukacyjnych

Zbyt powolna modernizacja kształcenia zawodowego w stosunku do działań w zakresie reform edukacji ogólnej

Dostosowanie systemu zarządzania i finansowania do reformy ustrojowej państwa
Rozbieżność między założeniami strategicznymi a polityką finansową w zakresie edukacji.

Brak świadomości polityków co do roli kształcenia zawodowego w rozwoju kraju.

Projekt reformy zawiera zbyt wiele niewiadomych w odniesieniu do kształcenia zawodowego.

Nadal niedoinwestowana infrastruktura i zasoby kształcenia zawodowego.

Brak jednoznaczności w określaniu zakresu kompetencji władz w odniesieniu do zarządzania (poziom województwa, kuratorium, gmin, ministerstw branżowych) i finansowania kształcenia zawodowego.

1999

Potrzeba przyszłościowej wizji systemu kształcenia i szkolenia zawodowego

Zintensyfikowanie prac nad programami nauczania w zakresie kształcenia i szkolenia zawodowego, modernizacja treści kształcenia zawodowego

Brak ugruntowanej, silnej pozycji kształcenia zawodowego w systemie edukacji.

Brak dobrze przygotowanych nauczycieli do udziału w reformowaniu kształcenia zawodowego.

Brak odpowiedniej infrastruktury i gwarantowanych w budżecie środków finansowych umożliwiających wprowadzenie zmian w treściach kształcenia i szkolenia zawodowego.

2002*

Weryfikacja założeń reformy z 1999 r. pod kątem miejsca i zadań kształcenia zawodowego $\mathrm{w}$ systemie edukacji

Potrzeba dyskusji z partnerami społecznymi na temat usytuowania kształcenia zawodowego na poziomie powiatów

Rozpoznanie potrzeb rynku pracy w zakresie popytu na określone kwalifikacje

Potrzeba reform w systemie poradnictwa zawodowego
Reforma nie uwzględnia roli i znaczenia praktycznego kształcenia w wykształceniu zawodowym.

Niedostateczna koordynacja działań w zakresie kształcenia zawodowego na poziomie powiatowym i wojewódzkim.

Brak ujęcia kształcenia zawodowego w perspektywie efektów kształcenia.

Brak bazy danych niezbędnych do konstrukcji prognoz. Utrzymujący się od lat brak rozwiązań prawnych w tym zakresie.

Niedocenianie w szkołach zawodowych i placówkach roli doradców zawodowych i ich działań.

\footnotetext{
* Potrzeby kształcenia zawodowego i przeszkody utrudniające ich realizację zgłaszane w latach 2000-2001 były zbieżne z tymi z 2002 r., dlatego je pominięto. Źródło: Raporty Narodowego Obserwatorium Kształcenia i Szkolenia Zawodowego opracowane przez Biura Koordynacji Kształcenia Kadr Fundacji Fundusz Współpracy w latach 1997-2002.
} 


\section{Ksztalcenie zawodowe w szkołach ponadgimnazjalnych}

Postulatem leżącym u podstaw reform tego segmentu edukacji jest dostosowanie do potrzeb rynku pracy. Tymczasem związek między kierunkami kształcenia i potrzebami rynku pracy jest wielopoziomowy, a w jego obrębie ujawniają się sprzeczności. Dostosowywanie edukacji do potrzeb rynku jest o tyle trudne, że rynek zmienia się szybciej niż system edukacji, a szczególnie system szkolny, który może na zmiany reagować z opóźnieniem (określone cykle kształcenia, programy nauczania, warunki kształcenia, kadra). W procesie tym w różnym zakresie biorą udział następujące podmioty: państwo, jednostki samorządu terytorialnego, instytucje edukacyjne ( $w$ tym szkoły), instytucje rynku pracy, partnerzy społeczni (pracodawcy, przedstawiciele poszczególnych branż i zawodów, związki zawodowe), szeroko pojęte otoczenie gospodarcze i społeczne. Każdy z tych podmiotów ma do spełnienia określone funkcje. Przykładowo państwo definiuje i wdraża podstawowe cele i standardy edukacyjne, w tym przygotowuje i wprowadza klasyfikację zawodów szkolnictwa zawodowego. Samorządy natomiast zakładają, prowadzą i finansują szkoły i placówki publiczne oferujące kształcenie zawodowe. Z kolei wspólnie ze szkołami planują kierunki kształcenia na podstawie obowiązujących przepisów i w rezultacie rozszerzają lub ograniczają kształcenie w określonych kierunkach - dokonuje się to na podstawie informacji płynących z rynku pracy (w praktyce z powiatowych urzędów pracy). Szkoły zaś wyposażają uczniów w wiedzę, umiejętności oraz kompetencje personalne i społeczne, kreują także (poprzez definiowanie i wdrażanie zadań z zakresu informacji i poradnictwa edukacyjno-zawodowego) postawy sprzyjające uzyskiwaniu pracy (Drogosz-Zabłocka 1999).

Reforma edukacji zapoczątkowana w 1999 r. była jedną z czterech wprowadzanych wówczas reform (poza administracyjną, emerytalną i zdrowia), ale na uwagę zasługuje fakt, że od początku swego funkcjonowania była przedmiotem badań (Konarzewski 2004). Odnosiły się one do ustroju szkolnego i infrastruktury oraz treści kształcenia. Badania prowadzone głównie przez Instytut Badań Edukacyjnych pokazywały szerszy kontekst reformy i dotykały problemów zarówno edukacyjnych (dydaktycznych, wychowawczych itp.), jak i społecznych, związanych z funkcjonowaniem zreformowanej edukacji. Ich wyniki pozwalają na podsumowanie mocnych stron i słabości tej reformy w perspektywie ponad piętnastoletniej. 
Reforma wprowadzała zmiany ustroju szkolnego i infrastruktury. Można to zatem uznać za zmiany w tym samym zakresie, co obecnie. Założenia reformy z 1999 r. zamknięto $w$ trzech obszarach:

1. podniesienie poziomu edukacji społeczeństwa przez upowszechnienie wykształcenia średniego i wyższego,

2. wyrównanie szans edukacyjnych,

3. poprawa jakości edukacji rozumianej jako integralny proces wychowania i kształcenia (Reforma systemu edukacji... 1998, s. 10).

Wprowadzenie gimnazjów miało służyć wyrównywaniu szans edukacyjnych i wydłużeniu kształcenia ogólnego, zmiany wprowadzane w edukacji koncentrowały się głównie na wykształceniu ogólnym. Intencją ustawodawcy było zachęcenie młodzieży do wyboru ogólnej ścieżki kształcenia i kontynuowania nauki na studiach. Technika i zasadnicze szkoły zawodowe miały zostać zastąpione przez licea o profilu zawodowym i dwuletnie szkoły zawodowe. Planów tych nie udało się zrealizować, ponieważ licea profilowane wykazały się słabymi wynikami zarówno w zakresie nauczania ogólnego (świadectwo dojrzałości), jak i w odniesieniu do rynku pracy (bezrobocie). Utrzymano więc dotychczasowe typy szkół kształcących zawodowo - trzyletnie zasadnicze szkoły zawodowe i czteroletnie technika. Dodatkowo stworzono technika i licea uzupełniające, które miały otwierać możliwości dalszej edukacji absolwentom zasadniczych szkół zawodowych. Oprócz zmiany struktury i pluralizmu programowego wprowadzono do systemu powszechne i jednolite egzaminy zewnętrzne, co miało wpływ na uzyskiwane wykształcenie zawodowe. Egzaminy z jednej strony miały być narzędziem kontroli nad pluralizmem programowym, z drugiej pozwalały na systematyczne badanie wyników nauczania i uzyskiwanych kwalifikacji. Brak jednolitych egzaminów zawodowych w skali kraju prowadził do nierównowartościowego wykształcenia zawodowego uzyskiwanego przez absolwentów tego samego typu szkół. Egzaminy zawodowe sprzed reformy sprowadzały się w większości wypadków do obrony pracy dyplomowej przygotowywanej samodzielnie przez ucznia w macierzystej szkole.

Pierwsza dekada lat dwutysięcznych to okres przygotowań do długo oczekiwanej reformy kształcenia zawodowego. W 2010 r. Krajowy Ośrodek Wspierania Edukacji Zawodowej i Ustawicznej (KOWEZiU) rozpoczął realizację kompleksowego badania mającego na celu wielo- 
wymiarową diagnozę stanu szkolnictwa zawodowego przed planowaną reformą. Wnioski z badań opublikowano w raporcie Stan szkolnictwa zawodowego w Polsce (KOWEZiU 2013). Jego autorzy zwracali uwage na powoli rosnące zainteresowanie młodzieży kształceniem zawodowym. Było to odwrócenie trendów obserwowanych do 2005 r. Z drugiej strony wyniki badań wskazywały na niską świadomość, zarówno uczniów, jak i rodziców, wartości kształcenia zawodowego oraz utrzymujące się negatywne opinie na temat szkół zawodowych.

Oferta dydaktyczna szkół kształcących zawodowo była przede wszystkim wypadkową zaplecza techniczno-dydaktycznego, zasobów kadrowych i kosztów, a w dużo mniejszym stopniu wynikiem analizy zapotrzebowania rynkowego i oferty kształcenia w regionie. Możliwość dofinansowania wyposażenia szkół ze środków UE, jaka pojawiła się po 2004 r., wpłynęła na systematyczną poprawę warunków kształcenia, jednak poziom wyposażenia warsztatów i pracowni był wciąż bardzo zróżnicowany i nadal ponad $80 \%$ dyrektorów badanych placówek deklarowało, że szkoły wymagają remontu. Wskazywano, że stan infrastruktury szkół zawodowych świadczy wciąż o głębokim niedoinwestowaniu. Jednocześnie sposób finansowania tych placówek prowadzi do systematycznego pogarszania się warunków lokalowych w nich panujących. Kolejnym problemem były narastające trudności z pozyskaniem nauczycieli przedmiotów zawodowych i instruktorów praktycznej nauki zawodu. Dużą część kadry pedagogicznej szkół kształcących zawodowo stanowiły osoby $\mathrm{w}$ wieku przedemerytalnym, a warunki zatrudnienia, które dyrektorzy mogliby zaoferować ich potencjalnym następcom, okazywały się mało atrakcyjne. Taka sytuacja zdaniem autorów diagnozy w dłużej perspektywie stanowiła poważne zagrożenie dla funkcjonowania systemu szkolnictwa zawodowego (KOWEZiU 2013). Realizowane w tym czasie projekty finansowane ze środków UE i adresowane do nauczycieli przedmiotów zawodowych („Efektywny nauczyciel sztuki kulinarnej-wdrożenie modelu”, „Efektywny nauczyciel przedmiotów ekonomicznych”, „Doskonalenie “chlebem powszednim” nauczyciela zawodu") także wskazywały na ubogą infrastrukturę i niedoinwestowane wyposażenie szkolnych pracowni i warsztatów, a także liczne braki w przygotowaniu nauczycieli przedmiotów zawodowych. Potwierdzają to poniższe wypowiedzi (Borys 2012): 
„Niezbyt kompetentnie się czuję czasem, bo jestem samoukiem, tzn. uczestniczyłam w jakimś szkoleniu z zakresu księgowości komputerowej, ale to jest tylko kurs. Natomiast nigdy nie widziałam, jak to w praktyce wygląda [...]. Sama opracowuję przykłady na lekcje, nie ma podręczników do tej pracowni [...] także przydałaby się praktyka w przedsiębiorstwie" (Borys 2012, s. 92).

"Lęk wynika z braku opanowania podstawowych umiejętności, chociażby krojenia. Nie jestem w stanie pokazać uczniom takiego krojenia jak ten pan, bo [...] nie robi się tego na co dzień" (tamże, s. 93).

„Wiedza książkowa jest nieaktualna. Ciągle mam poczucie, że czegoś nie wiem [...] i ciągle w internecie wertuję i wydaje mi się, że nie do końca, cały czas tak jest" (tamże, s. 93).

Przywoływaną diagnozę przeprowadzono u progu istotnych zmian, które zaszły w polskim szkolnictwie zawodowym po 2012 r. Reforma szkolnictwa zawodowego miała z jednej strony stanowić odpowiedź na wyzwania tego sektora, z drugiej była konsekwencją procesów integracji europejskiej i dostosowywania polskiego systemu szkolnictwa zawodowego do standardów UE. Wiązało się to $z$ wprowadzaniem w Polsce ogólnoeuropejskich rozwiązań systemowych, które mają zapewnić większą transparentność, porównywalność i wzajemne uznawanie kwalifikacji osób uczących się i pracowników na terenie UE. Są to:

1. Europejska Rama Kwalifikacji (EQF) - pozwala na uznawanie efektów uczenia się niezależnie od formy i miejsca kształcenia. Wskazuje na wiedzę, umiejętności i kompetencje właściwe każdemu z ośmiu wyróżnionych poziomów kwalifikacji. Polski opis hierarchii poziomów kwalifikacji - Polska Rama Kwalifikacji znajduje odniesienie do Europejskiej Ramy Kwalifikacji w raporcie referencyjnym opublikowanym w $2013 \mathrm{r}$.

2. Europejski System Transferu Osiągnięć w Kształceniu i Szkoleniu Zawodowym (ECVET) - stwarza możliwość akumulowania, wzajemnego uznawania i przenoszenia efektów uczenia się między różnymi instytucjami kształcącymi zawodowo. 


\section{Europejskie Ramy Odniesienia na Rzecz Zapewnienia Jakości} w Kształceniu i Szkoleniu Zawodowym (EQAVET) - jest to zestaw projakościowych zaleceń odnoszących się do wszystkich etapów kształcenia zawodowego, od jego planowania, przez sam tok nauki, po ocenę wyników i standardów egzaminowania.

4. Projekt Europass - umożliwia stworzenie uniwersalnych standardów czytelnego prezentowania kompetencji i umiejętności zawodowych, m.in. przez wprowadzenie i promocję wzorów dokumentów: Curriculum Vitae, Paszportu Językowego czy Suplementów do Dyplomów.

Rozwiązania te mają naturalnie wspierać funkcjonowanie jednolitego rynku UE, opartego na pryncypiach swobodnego przepływu osób, kapitału, towarów i usług. Zmiany te istotnie wpłynęły na sposób myślenia o edukacji, w szczególności zaś o kształceniu zawodowym - oznacza to przede wszystkim przesunięcie akcentu z procesu kształcenia na jego efekty i uelastycznienie systemu edukacji tak, aby mógł lepiej sprostać wyzwaniom współczesnego rynku pracy.

Warto podkreślić, że rozpoczęta w 2012 r. reforma kształcenia zawodowego nabrała nowego wymiaru po 2016 r. (m.in. z powodu zmiany struktury systemu edukacji i wprowadzenia do niego nowych typów szkół, w tym branżowych szkół I i ll stopnia). Tylko niektóre z tych zmian, szczególnie te wprowadzone w roku szkolnym 2018/2019, zasygnalizujemy w naszej publikacji.

Wyrazem zmiany myślenia o edukacji była reforma edukacji z 2012 r., która w znacznym stopniu uelastyczniła system kształcenia zawodowego. Na reformę składały się m.in. nowelizacja ustawy o systemie oświaty z 2012 r., wprowadzenie nowej podstawy programowej kształcenia $w$ zawodach, modernizacja i ujednolicenie systemu egzaminów zewnętrznych oraz zbudowana na nowych podstawach uwzględniających efekty uczenia się klasyfikacja zawodów szkolnictwa zawodowego. Tak zwana szkolna klasyfikacja zawodów została już we wcześniejszych latach powiązana z klasyfikacją zawodów i specjalności występujących na rynku pracy, co przynajmniej w zakresie spójności tych dwóch dokumentów było ważnym wydarzeniem. Zawody nauczane w systemie oświaty zostały uporządkowane według tego samego klucza, co zawody występujące w klasyfikacji dla rynku pracy (grupy zawodów i przypisane 
im symbole cyfrowe). Szkolna klasyfikacja zawodów z 2017 r. ${ }^{6}$ stała się swoistym schematem-kluczem do opisu zawodu szkolnego, zawierała bowiem, oprócz wskazanych powyżej informacji, także: nazwy szkół ponadpodstawowych, w których odbywa się kształcenie, nazwy kwalifikacji wyodrębnionych w zawodzie7, nazwy kwalifikacji, dla których przewidziano możliwość prowadzenia kształcenia na kwalifikacyjnych kursach zawodowych i obszary kształcenia, do których są przypisane zawody. Odnosi się również do Polskiej Ramy Kwalifikacji, a także zawiera opis szczegółowych uwarunkowań lub ograniczeń związanych z wykonywaniem danego zawodu.

Zapoczątkowane w 2012 r. zmiany w zakresie kształcenia zawodowego miały także wpływ na kształcenie ustawiczne, którego możliwości zwiększono przez wprowadzenie różnych pozaszkolnych form kształcenia. Są to w szczególności: kwalifikacyjne kursy zawodowe, kursy umiejętności zawodowych, kursy kompetencji ogólnych i inne8. Innowacją, która znacząco uelastyczniła system kształcenia zawodowego - w szczególności osób dorosłych - było wprowadzenie nowej pozaszkolnej formy kształcenia - kwalifikacyjnych kursów zawodowych? Zarówno uczestnicy kursów, jak i osoby zdobywające kwalifikacje w toku edukacji nieformalnej mogą potwierdzić swoje kwalifikacje w drodze egzaminów eksternistycznych. Zmiany te wpłynęły przede wszystkim na organizację kształcenia dorosłych - z licznych typów szkół ponadpodstawowych pozostawiono dla nich jedynie licea, a uzupełniać kwalifikacje zawodowe mogli w formach kursowych ${ }^{10}$.

Opracowana wówczas podstawa programowa miała zapewnić zgodność kształcenia zawodowego z wymaganiami gospodarki

6 Rozporządzenie Ministra Edukacji Narodowej z 13 marca 2017 r. w sprawie klasyfikacji zawodów szkolnictwa zawodowego, Dz.U. 2017 poz. 622, znowelizowane dnia 7 grudnia 2017 r. Jest to obowiązujący akt prawny.

7 W znowelizowanym rozporządzeniu z 2017 r. podano ogólne symbole kwalifikacji, np. K1, K2. W odniesieniu do zawodu technik informatyk są to: K1 - Montaż i eksploatacja systemów komputerowych, urządzeń peryferyjnych i sieci, K2 - Programowanie, tworzenie i administrowanie stronami internetowymi i bazami danych. młodocianych pracowników. zawodów ujętych w klasyfikacji zawodów szkolnictwa zawodowego.

10 Obecnie powrócono do rozwiązań wcześniejszych, oferujących większą gamę szkół ponadpodstawowych ogólnokształcących i zawodowych dla dorosłych. 
i wpłynąć na polepszenie jego jakości. Nowy dokument, przygotowany dla 193 zawodów, został podzielony na trzy części. W części l opisano cele i zadania kształcenia zawodowego, zamieszczono nazwy obszarów kształcenia oraz spis wszystkich kwalifikacji wyodrębnionych w zawodach. Pierwotnie wyróżniono zawody jedno-, dwu-i trzykwalifikacyjne ${ }^{11}$. Część Il zawierała efekty kształcenia wspólne dla wszystkich zawodów w zakresie: zasad BHP, podejmowania i prowadzenia działalności gospodarczej, języka obcego ukierunkowanego zawodowo, kompetencji personalnych i społecznych oraz organizacji pracy małych zespołów (w przypadku techników i szkół policealnych), a także efekty kształcenia wspólne dla danego obszaru zawodowego ${ }^{12}$ i właściwe dla kwalifikacji w danym zawodzie. Część III odnosiła się wprost do procesu dydaktycznego i zawierała cele kształcenia zapisane w języku efektów kształcenia określonym dla danego zawodu, nazwy kwalifikacji, opis warunków kształcenia, tj. wymagany sprzęt i wyposażenie pracowni, minimalną liczbę godzin kształcenia zawodowego oraz możliwości uzyskiwania dodatkowych kwalifikacji przewidzianych w systemie szkolnym. Należy podkreślić, że taka konstrukcja podstawy programowej w zasadniczy sposób odbiegała od dotychczasowych podstaw obowiązujących w kształceniu zawodowym (trzy części podstawy) i stanowiła pewien problem dla nauczycieli i dyrektorów szkół korzystających z tego dokumentu, a przede wszystkim tworzących na jego podstawie programy nauczania. Problemem było jego scalenie i utworzenie jednolitej, ale odbiegającej w swej konstrukcji od dokumentu wyjściowego podstawy programowej. Doświadczenia te pokazują, jak ważne są badania edukacyjne nad wprowadzanymi do praktyki szkolnej podstawami programowymi i tworzonymi na ich podstawie programami nauczania. Badania pilotażowe mogłyby już na etapie tworzenia podstaw programowych pomóc uniknąć pewnych rozwiązań wprowadzanych do praktyki szkolnej, które na etapie pracy koncepcyjnej wydają się korzystne i uzasadnione.

11 Jedynie w przypadku zawodów artystycznych nie zdecydowano się na wyodrębnienie kwalifikacji.

12 Wyróżniono osiem różnych obszarów: administracyjno-usługowy, budowlany, elektryczno-elektroniczny, mechaniczny i górniczo-hutniczy, rolniczo-leśny z ochroną środowiska, turystyczno-gastronomiczny, medyczno-społeczny oraz artystyczny. 
Podstawa programowa zawierała także wymagania egzaminacyjne, co było istotnym novum. Integrowała bowiem w sobie dwa dotychczas obowiązujące dokumenty: podstawy programowe i wymagania egzaminacyjne. Poszczególne kwalifikacje wymagają potwierdzenia w drodze zewnętrznych egzaminów - dopiero komplet zdanych egzaminów $z$ kwalifikacji wyodrębnionych $w$ danym zawodzie wraz ze świadectwem ukończenia odpowiedniej szkoły ${ }^{13}$ dają prawo do uzyskania dyplomu potwierdzającego kwalifikacje zawodowe. Każda kwalifikacja składająca się na dany zawód wymaga potwierdzenia i uzyskania świadectwa. Dopiero po potwierdzeniu każdej z kwalifikacji i zebraniu wszystkich świadectw wymaganych w danym zawodzie uczeń może otrzymać dyplom potwierdzający kwalifikacje. W praktyce tak zorganizowane egzaminy przyczyniały się z jednej strony do większej elastyczności systemu egzaminowania, $z$ drugiej jednak prowadziły do pewnej dezorganizacji pracy szkoły, udostępniającej pracownie szkolne czy laboratoria do organizacji egzaminów. W jeszcze trudniejszej sytuacji znalazły się Centra Kształcenia Praktycznego, które udostępniały swoje zasoby wielu szkołom i musiały pogodzić zadania wynikające z realizacji programu nauczania z tymi, które nakładała na nie organizacja egzaminów zawodowych.

Oceny pierwszych skutków reformy z 2012 r. dokonała Najwyższa Izba Kontroli (NIK) w ramach kontroli planowej, której wyniki przedstawiono w publikacji "System szkolnictwa zawodowego (P/15/029)" w 2015 r. (Informacja... 2015). W opinii NIK system szkolnictwa zawodowego "nie jest w pełni skuteczny" ze względu na niedopasowanie oferty szkół kształcących zawodowo do zapotrzebowania ze strony pracodawców. NIK wskazuje na stosunkowo wysoki poziom bezrobocia wśród absolwentów szkół kształcących zawodowo oraz niskie oceny ich kompetencji wystawiane przez pracodawców (powołuje się tu na wyniki badań Bilansu Kapitału Ludzkiego, zob. Górniak 2015). Całościowa ocena skutków reformy wymagałaby zamknięcia pełnego cyklu kształcenia wedle nowych podstaw programowych. Niemniej już wówczas widoczne były problemy z finansowaniem reformy - w szczególności nieuwzględnienie zróżnicowanych kosztów kształcenia w zawodach w algorytmie subwencji oświatowej. Zdaniem kontrolerów NIK taka

13 W szczególnych przypadkach może być zastąpiony zdaniem odpowiedniego egzaminu eksternistycznego. 
sytuacja sprawiała, że o strukturze kształcenia w danym regionie decydowały możliwości kadrowe i dotychczasowa baza technodydaktyczna, a potrzeby uczniów i pracodawców miały drugorzędne znaczenie. Sytuację pogarszał źle funkcjonujący system doradztwa zawodowego dla młodzieży, problem nierozwiązany od lat, co ilustrowały raporty z końca lat 90. (tabela 1). Ponadto infrastruktura szkół kształcących zawodowo, mimo znaczącego wsparcia ze środków europejskich, była w dużej mierze przestarzała. Utrudniało to realizację kształcenia wedle standardów technologicznych, których oczekiwaliby pracodawcy.

Wprowadzane obecnie zmiany w klasyfikacji zawodów ${ }^{14}$, które będą obowiązywać od 1 września 2019 r., dotyczą kilku obszarów: zdefiniowania celów i zadań kształcenia w zawodach szkolnictwa branżowego, wprowadzenia nowej, dotychczas niefunkcjonującej, klasyfikacji zawodów szkolnictwa branżowego, zdefiniowania 32 branż zawodowych (w miejsce ośmiu obszarów kształcenia zawodowego), wprowadzenia nowych zawodów oraz uporządkowania i zmian symboli i nazw kwalifikacji wyodrębnionych w zawodzie.

\section{Wykształcenie zawodowe - instytucje i ścieżki kształcenia prowadzące do jego uzyskania ${ }^{15}$}

\section{Struktura kształcenia zawodowego w Polsce}

Podstawy funkcjonowania systemu kształcenia zawodowego w Polsce reguluje obecnie, już kilkakrotnie nowelizowana, Ustawa z dnia 14 grudnia 2016 r. Prawo oświatowe ${ }^{16}$, która zastąpiła Ustawę z dnia 7 września 1991 r. o systemie oświaty.

Ostatnia z reform systemu edukacji, wdrażana od początku 2016 r., zmieniła cały sposób jego organizacji. Likwidacja gimnazjów i wprowadzenie ośmioletnich szkół podstawowych wpłynęły również na organizację kształcenia na poziomie ponadpodstawowym. Ponadto w opinii przedstawicieli resortu edukacji w obszarze kształcenia zabranżowego (Dz.U. 2019 poz. 316). 
wodowego niezbędne są zmiany, które pozwolą rozwiązać najbardziej palące problemy, z którymi od lat borykają się szkoły kształcące zawodowo. W znowelizowanej w listopadzie 2018 r. ustawie Prawo oświatowe i wprowadzonych na jej podstawie aktach wykonawczych ujęto już część (obowiązujących w większości przypadków od 1 września 2019 r.) postulowanych w poniższej tabeli rozwiązań.

Warto zwrócić uwagę, że część z nich (np. w obszarze kształcenia dualnego i gratyfikacji dla pracodawców zaangażowanych w Praktyczną Naukę Zawodu - PNZ) funkcjonowała już przed wprowadzeniem reformy, a inne (m.in. doposażanie szkół i centrów kształcenia praktycznego-CKP) ${ }^{17}$, stypendia, finansowanie dodatkowych uprawnień branżowych dla uczniów, staże) realizowano po 2012 r. dzięki wsparciu ze środków UE. Najtrudniejszym elementem reformy systemu kształcenia zawodowego pozostaje kwestia wygospodarowania adekwatnych środków finansowych oraz stworzenia trwałego modelu finansowania dla proponowanych rozwiązań. Jedną z najbardziej wymiernych zmian, które wprowadzono w ramach Ustawy z dnia 14 grudnia 2016 r. Prawo oświatowe, jest wspomniana organizacja kształcenia zawodowego i idące za tym zmiany programowe. Na uwagę zasługują także działania podejmowane $w$ zakresie doradztwa zawodowego ${ }^{18}$, które wpisują się w realizowane w Polsce eurodoradztwo, mające na celu wspieranie zawodowej i edukacyjnej mobilności obywateli oraz rozwój poradnictwa zawodowego w Europie. W ramach eurodoradztwa upowszechnia się informacje na temat narzędzi oraz metod i technik poradnictwa zawodowego, opracowuje się publikacje z tego zakresu i promuje się współpracę z sieciami działającymi na rzecz mobilności i uznawania kwalifikacji (eurodoradztwo.praca.gov.pl). wiedzy, umiejętności i kwalifikacji zawodowych. 


\section{Tabela 2. Zidentyfikowane problemy i proponowane zmiany \\ w reformie systemu edukacji w 2016 r.}

\begin{tabular}{|c|c|}
\hline Zidentyfikowane problemy & Postulowane rozwiązania i kierunki zmian \\
\hline $\begin{array}{l}\text { Niedopasowanie struktu- } \\
\text { ry i efektów kształcenia } \\
\text { zawodowego do potrzeb } \\
\text { rynku pracy }\end{array}$ & $\begin{array}{l}\text { Uwzględnienie potrzeb lokalnego i regionalnego rynku pracy przy tworzeniu } \\
\text { nowych zawodów i zmianach w zakresie podstaw programowych. Szersze } \\
\text { włączenie pracodawców w proces ustalania struktury i programów } \\
\text { kształcenia zawodowego }{ }^{19} \text {. } \\
\text { Finansowanie dodatkowych uprawnień branżowych dla uczniów szkół } \\
\text { kształcących zawodowo }{ }^{20} \text {. }\end{array}$ \\
\hline $\begin{array}{l}\text { Niewystarczające zaan- } \\
\text { gażowanie pracodawców } \\
\text { w praktyczną naukę } \\
\text { zawodu }\end{array}$ & $\begin{array}{l}\text { Wzmacnianie modelu kształcenia dualnego (realizacja praktycznej nauki za- } \\
\text { wodu u pracodawców i klasy patronackie). Gratyfikacje finansowe dla praco- } \\
\text { dawców, dodatki motywacyjne dla instruktorów praktycznej nauki zawodu }{ }^{21} \text {. }\end{array}$ \\
\hline $\begin{array}{l}\text { Małe zainteresowanie } \\
\text { kształceniem zawodo- } \\
\text { wym ze strony młodzieży } \\
\text { - negatywna selekcja do } \\
\text { szkół zawodowych } \\
\text { Zły wizerunek zasadni- } \\
\text { czych szkół zawodowych } \\
\text { wśród uczniów i rodziców }\end{array}$ & $\begin{array}{l}\text { Zmiana struktury kształcenia zawodowego poprzez wprowadzenie nowych } \\
\text { typów szkół (szkoły branżowe), które będą ukierunkowane przede wszyst- } \\
\text { kim na praktyczne kształcenie zawodowe, nie zamykając drogi do zdobycia } \\
\text { wykształcenia średniego }{ }^{22} \text {. } \\
\text { Promocja pozytywnego wizerunku kształcenia zawodowego. Stosowanie } \\
\text { zachęt stypendialnych. }\end{array}$ \\
\hline $\begin{array}{l}\text { Przestarzała baza tech- } \\
\text { no-dydaktyczna szkół, } \\
\text { zwłaszcza w zakresie } \\
\text { wyposażenia pracowni do } \\
\text { realizacji praktycznej nauki } \\
\text { zawodu }\end{array}$ & $\begin{array}{l}\text { Przyznanie centrom kształcenia praktycznego (CKP) głównej } \\
\text { odpowiedzialności za koordynację kształcenia zawodowego (w szkołach } \\
\text { lub u pracodawców) i realizację egzaminów zawodowych na poziomie } \\
\text { powiatów (w przyszłości CKP mają pełnić rolę ośrodków certyfikujących } \\
\text { Zintegrowanego Systemu Kwalifikacji). CKP, doposażone w nowoczesny } \\
\text { sprzęt i urządzenia, będą wspierać szkoły lub pracodawców w realizacji } \\
\text { praktycznej nauki zawodu }{ }^{23} \text {. }\end{array}$ \\
\hline
\end{tabular}
o wspieraniu kształcenia zawodowego przez pracodawców i ich organizacje, samorządy gospodarcze i inne organizacje gospodarcze, a także przez Radę Programową ds. Kompetencji. W ustawie określono także zakres wsparcia szkolnictwa zawodowego przez pracodawców.

Istnieje możliwość zawarcia umowy przez dyrektora szkoły z instytucją certyfikującą, co umożliwi uczniowi walidacje i certyfikowanie kwalifikacji rynkowej ujętej w Zintegrowanym Systemie Kwalifikacji (Dz.U. 2018 poz. 2245 art. 122a ust. 1).

$21 \quad$ Ustalono zasady współpracy szkoły z pracodawcami. Określają one m.in. przygotowanie propozycji programowych, udział w organizacji egzaminu zawodowego, realizację doradztwa zawodowego i promocji kształcenia zawodowego czy doskonalenie nauczycieli kształcenia zawodowego, w tym organizowanie szkoleń branżowych (Dz.U. 2018 poz. 2245 art. 68 ust. 7c).

22 Tamże.

23 Tamże. Zmiana od 1 września 2019 r. centrów kształcenia praktycznego na centra kształcenia zawodowego. 

Fasadowy, źle funkcjonują-
cy system doradztwa zawo-
dowego w szkołach

Poważne braki w zakresie kadry nauczycielskiej szkół kształcących zawodowo, w szczególności nauczycieli przedmiotów zawodowych

Brak rozwiązań instytucjonalnych pozwalających na sprawne finasowanie planowanych zmian oraz doposażenia szkół/CKP
Usprawnienie systemu doradztwa zawodowego poprzez: uwzględnienie jego elementów w podstawach programowych, wprowadzenie ramowych programów doradztwa i obowiązku badań predyspozycji zawodowych w poradniach psychologiczno-pedagogicznych przez wyborem ścieżki kształcenia24.

Utworzenie „Korpusu Fachowców" - nauczycieli i instruktorów praktycznej nauki zawodu rekrutujących się z wysokiej klasy specjalistów pozyskanych z przedsiębiorstw lub nauczycieli - emerytów. Dodatkowo utworzony zostanie portal edukacyjno-zawodowy na poziomie województwa, który będzie odpowiedzią na brak informacji dotyczącej potrzeb oraz możliwości w zakresie kształcenia praktycznego u pracodawców, zarówno po stronie szkoły, jak i pracodawcy.

Utworzenie Funduszu Rozwoju Edukacji Zawodowej. Wśród potencjalnych źródeł finansowania wskazuje się środki Funduszu Pracy, spółki Skarbu Państwa lub składki od zrzeszonych przedsiębiorców.

Źródło: gov.pl/web/edukacja [dostęp: 23.10.2018].

W okresie przejściowym wprowadzania reformy edukacji absolwenci wygaszanych gimnazjów mogą wybrać spośród następujących typów szkół kształcących zawodowo:

$\rightarrow$ branżowe szkoły I stopnia - trzyletnie szkoły ponadpodstawowe przygotowujące do egzaminów potwierdzających kwalifikacje w zawodzie. W latach szkolnych 2017/2018 i 2019/2020 branżowe szkoły I stopnia będą prowadzić klasy wygaszanych zasadniczych szkół zawodowych. Uczniowie wygaszanych szkół, którzy nie otrzymają promocji do następnej klasy, będą kontynuować naukę już w odpowiednich klasach branżowej szkoły I stopnia. Pierwsi absolwenci branżowych szkół I stopnia ukończą naukę w $2020 \mathrm{r}$.

$\rightarrow$ technika - czteroletnie szkoły ponadpodstawowe przygotowujące do egzaminu maturalnego oraz do egzaminów potwierdzających kwalifikacje w zawodzie. Rekrutacja w tych szkołach będzie otwarta dla absolwentów gimnazjów do roku szkolnego

24 Zadania te będą realizowane w szkołach zgodnie ze znowelizowaną ustawą Prawo oświatowe z 22 listopada 2018 r. oraz wcześniejszym Rozporządzeniem Ministra Edukacji Narodowej z dnia 16 sierpnia 2018 r. w sprawie doradztwa zawodowego (Dz.U. 2018 poz. 1675). Treści programowe z zakresu doradztwa oraz zadania doradcy zawodowego zostały określone w Rozporządzeniu. W latach 2016-2018 Ośrodek Rozwoju Edukacji (ORE) realizował projekty z tego zakresu finansowane ze środków Programu Operacyjnego Wiedza Edukacja Rozwój (PO WER). 
2019/2020, w tym samym roku absolwenci ośmioletnich szkół podstawowych będą już rekrutowani do techników pięcioletnich. Od 1 września 2020 r. nie będzie już naboru do czteroletnich techników, a szkoły te będą sukcesywnie wygaszane - uczniowie, którzy nie uzyskają promocji do kolejnej klasy, będą kontynuować naukę już w odpowiedniej klasie pięcioletniego technikum.

Wdrażana reforma oznacza również stopniowe wygaszanie gimnazjów dla dorosłych, przekształcenie trzyletnich liceów dla dorosłych w czteroletnie szkoły dla dorosłych. Szkoły policealne będą funkcjonowały na dotychczasowych zasadach, podobnie jak trzyletnie szkoły specjalne przysposabiające do prac. Docelowo absolwenci ośmioletnich szkół podstawowych mogą wybrać spośród następujących typów szkół kształcących zawodowo:

$\rightarrow$ branżowe szkoły I stopnia - trzyletnie szkoły ponadpodstawowe przygotowujące do egzaminów potwierdzających kwalifikacje w zawodzie;

$\rightarrow$ technika - pięcioletnie szkoły ponadpodstawowe przygotowujące do egzaminu maturalnego oraz egzaminów potwierdzających kwalifikacje w zawodzie;

$\rightarrow$ od 1 września 2020 r. branżowe szkoły Il stopnia, w których naukę będą mogli kontynuować pierwsi absolwenci branżowych szkół I stopnia. Branżowe szkoły Il stopnia będą oferowały kształcenie wyłącznie w tych zawodach, które stanowią kontynuację kształcenia w branżowej szkole I stopnia, ponieważ w zawodzie nauczanym w branżowej szkole l i ll stopnia wyodrębniono wspólną pierwszą kwalifikację. W praktyce oznacza to, że szkoły branżowe II stopnia będą dostępne dla tych absolwentów branżowych szkół I stopnia, którzy uzyskali w niej pierwszą kwalifikację wspólną dla zawodu nauczanego na poziomie branżowej szkoły I stopnia i technikum. Druga kwalifikacja cząstkowa z poziomu technikum będzie natomiast nauczana w branżowej szkole II stopnia. Absolwenci branżowych szkół I stopnia, dla których nie ma kierunkowej drugiej kwalifikacji w zawodzie w technikum, będą mogli kontynuować naukę w liceum ogólnokształcącym 
dla dorosłych od drugiej klasy25. Uczniowie branżowych szkół II stopnia, podobnie jak absolwenci techników, będą mieli możliwość przystąpienia zarówno do egzaminu maturalnego, jak i do egzaminu potwierdzającego kwalifikacje $\mathrm{w}$ danym zawodzie ( $w$ miejsce dodatkowego obowiązkowego przedmiotu zdawanego na maturze przez absolwentów techników i liceów).

Wspomniane szkoły kształcące zawodowo opierają swoją działalność na dwojakich podstawach programowych - kształcenia ogólnego oraz na podstawie programowej kształcenia w zawodach. Kierunek reform szkolnictwa zawodowego z 2012 r. został utrzymany, jednak w związku ze zmianą organizacji systemu kształcenia oraz koniecznością dalszego dostosowywania systemu kształcenia zawodowego do potrzeb rynku pracy wprowadzono tu różne modyfikacje.

Rozporządzenie Ministra Edukacji Narodowej z dnia 13 marca 2017 r. w sprawie klasyfikacji zawodów szkolnictwa zawodowego wyróżnia 213 zawodów, których nauka może być prowadzona w pięcioletnim technikum, trzyletniej branżowej szkole I stopnia, dwuletniej branżowej szkole II stopnia, szkołach policealnych oraz, stopniowo wygaszanych, klasach czteroletnich techników. Rozporządzenie wprowadza kilka nowych ${ }^{26}$ zawodów oraz zmiany w zakresie kwalifikacji przyporządkowanych do 54 zawodów. Były to zawody trójkwalifikacyjne. Modyfikacja w zakresie liczby kwalifikacji składających się na dany zawód i podstaw programowych kształcenia w tych zawodach była przygotowana w ramach projektu "Partnerstwo na rzecz kształcenia zawodowego" przez ORE w ramach PO WER. W projekcie tym wypracowano rozwiązania zaadaptowane do zmian w klasyfikacji zawodów i podstaw programowych kształcenia w zawodzie. Zmodyfikowane podstawy programowe z 2017 r. obowiązywały w branżowej szkole I stopnia po gimnazjum i czteroletnim technikum. Kolejne zmiany wynikające z realizacji na2019 r. w sprawie ogólnych celów i zadań kształcenia w zawodach szkolnictwa branżowego oraz klasyfikacji zawodów szkolnictwa branżowego (Dz.U. 2019 poz. 316). 
stępnych etapów tego projektu będą wprowadzane od 1 września 2019 r. 27

\section{Podstawy programowe}

W nowej klasyfikacji zawodów szkolnictwa branżowego z 2019 r. zawody jednokwalifikacyjne są zawodami nauczanymi przede wszystkim w branżowej szkole I stopnia, w technikum dominują zawody dwukwalifikacyjne. Pierwszą kwalifikacją nauczaną w technikum jest w wielu przypadkach kwalifikacja wyodrębniona w zawodzie nauczanym w branżowej szkole I stopnia28. Od 1 września 2019 r. będzie obowiązywać nowa podstawa programowa w zawodach szkolnictwa branżowego 29 .

Równolegle do opisywanych zmian powstał tzw. Zintegrowany Rejestr Kwalifikacji, tj. publiczne repozytorium wszystkich kwalifikacji nadawanych w Polsce, prowadzone przez Instytut Badań Edukacyjnych. W rejestrze znajdują się już wszystkie kwalifikacje pełne, tzn. nadawane w ramach systemu oświaty i szkolnictwa wyższego. Każda z kwalifikacji włączonych do rejestru jest opisana wedle tego samego schematu i ma przypisany odpowiedni poziom Polskich Ram Kwalifikacji. Obecnie trwa złożony proces włączania do rejestru tzw. kwalifikacji cząstkowych, głównie kwalifikacji rynkowych zgłaszanych przez rozmaite podmioty działające na styku edukacji, rynku pracy i gospodarki.

\section{Praktyczna nauka zawodu}

Kluczowym elementem kształcenia zawodowego, przesądzającym o jego specyfice i odróżniającym je od edukacji ogólnokształcącej, jest praktyczna nauka zawodu (PNZ) ${ }^{30}$. Może ona odbywać się w postaci: programowej kształcenia w zawodach, Dz.U. 2017 poz. 860.

28 Rozporządzenie Ministra Edukacji Narodowej z dnia 15 lutego 2019 r.

29 Rozporządzenie Ministra Edukacji Narodowej w sprawie podstawy programowej kształcenia w zawodach szkolnictwa branżowego oraz dodatkowych umiejętności zawodowych w zakresie wybranych zawodów szkolnictwa branżowego zostało podpisane 16 maja 2019 r. (Dz.U. 2019 poz. 991).

30 Sposób jej realizacji regulować będzie od 1 września 2019 r. Rozporządzenie Ministra Edukacji Narodowej z dnia 22 lutego 2019 r. w sprawie praktycznej nauki zawodu (Dz.U. 2019 poz. 391). Opis realizacji PNZ ma swoje odniesienie do tego dokumentu. 
$\rightarrow$ zajęć praktycznych - organizowanych dla uczniów i młodocianych w celu wyposażenia ich w niezbędne umiejętności zawodowe. Zwykle odbywają się one w czasie zajęć dydaktyczno-wychowawczych, ale - w przypadku zajęć prowadzonych u pracodawcy na zasadzie dualnego systemu kształcenia - mogą być również przeprowadzane w trakcie ferii letnich. Celem zajęć praktycznych realizowanych u pracodawcy jest dodatkowe zastosowanie i pogłębienie zdobytej wiedzy i umiejętności zawodowych w rzeczywistych warunkach pracy. Zajęcia praktyczne prowadzą nauczyciele lub, w przypadku zajęć odbywających się u pracodawców $i$ w indywidualnych gospodarstwach rolnych, delegowani do takich zadań pracownicy jako tzw. instruktorzy praktycznej nauki zawodu. Osoby te muszą spełniać wymagania określone w Rozporządzeniu - w szczególności mieć odpowiednie wykształcenie, doświadczenie i przygotowanie pedagogiczne.

$\rightarrow$ praktyk zawodowych - organizowanych dla uczniów w celu zastosowania i pogłębienia zdobytej wiedzy i umiejętności zawodowych w rzeczywistych warunkach pracy. Mogą one odbywać się w czasie całego roku szkolnego, także w okresie ferii letnich. Za nadzór nad praktykantami zawodowymi u pracodawcy odpowiada pracodawca lub wyznaczony przez niego opiekun praktyk zawodowych lub osoba prowadząca indywidualne gospodarstwo rolne. Opiekun praktyk zawodowych może zostać częściowo lub całkowicie zwolniony ze świadczenia pracy - zależy to od rodzaju świadczonej pracy lub liczby uczniów odbywających praktyki zawodowe. Za czas zwolnienia od pracy na rzecz opieki nad praktykantami opiekun może otrzymać wynagrodzenie zgodnie z zasadami określonymi w Rozporządzeniu. 
Tabela 3. Organizacja praktycznej nauki zawodu w zależności

od podmiotu organizującego kształcenie

\begin{tabular}{l|l|l|l} 
& $\begin{array}{l}\text { pracodawca przyjmujący } \\
\text { młodocianych }\end{array}$ & $\begin{array}{l}\text { branżowe szkoły } \\
\text { I ill stopnia, technika, } \\
\text { szkoły policealne }\end{array}$ & $\begin{array}{l}\text { branżowe szkoły } \\
\text { II stopnia, technika } \\
\text { i szkoły policealne }\end{array}$ \\
\hline \multirow{2}{*}{ formy PNZ } & $\begin{array}{l}\text { zajęcia praktyczne na } \\
\text { zasadzie dualnego systemu } \\
\text { kształcenia }\end{array}$ & $\begin{array}{l}\text { zajęcia praktyczne, } \\
\text { w tym realizowane } \\
\text { na zasadzie dualnego } \\
\text { systemu kształcenia }\end{array}$ & $\begin{array}{l}\text { w tym realizowa- } \\
\text { ne na zasadzie } \\
\text { dualnego systemu } \\
\text { kształcenia oraz } \\
\text { praktyki zawodowe }\end{array}$ \\
\hline $\begin{array}{l}\text { organizator kształcenia } \\
\text { miejsce realizacji PNZ }\end{array}$ & $\begin{array}{l}\text { pracodawca } \\
\text { pospodarstwo rolne } \\
\text { (na zasadzie dualnego } \\
\text { systemu kształcenia) }\end{array}$ & $\begin{array}{l}\text { kształcenia ustawicznego, centra } \\
\text { kształcenia zawodowego, u pracodawcy, } \\
\text { w indywidualnym gospodarstwie rolnym }\end{array}$ \\
\hline $\begin{array}{l}\text { podstawa prawna } \\
\text { w przypadku realizacji PNZ } \\
\text { u pracodawcy }\end{array}$ & $\begin{array}{l}\text { umowa o pracę w celu } \\
\text { przygotowania zawodowe- } \\
\text { go między młodocianym } \\
\text { a pracodawcą }\end{array}$ & $\begin{array}{l}\text { umowa o praktyczną naukę zawodu } \\
\text { między dyrektorem szkoły a pracodawcą }\end{array}$
\end{tabular}

Źródło: opracowanie własne na podstawie Rozporządzenia MEN z dnia 28 lutego 2019 r.

w sprawie praktycznej nauki zawodu (Dz.U. 2019 poz. 391).

Szkoła ma do wyboru różne rozwiązania w kwestii miejsca realizacji praktyk lub zajęć praktycznych - począwszy od własnych pracowni i warsztatów, przez finansowane ze środków samorządu placówki kształcenia ustawicznego/praktycznego, kończąc na pracodawcach, z którymi nawiąże współpracę. W tym miejscu warto wspomnieć o szczególnych typach placówek pozaszkolnych, które odgrywają szczególną rolę w organizacji i prowadzeniu PNZ. Od 1 września 2019 r. będę pełnić tę funkcję:

$\rightarrow$ centra kształcenia zawodowego (CKZ) - umożliwiające uzyskanie i uzupełnienie wiedzy, umiejętności i kwalifikacji zawodowych,

$\rightarrow$ placówki kształcenia ustawicznego (PKU) - realizujące te same zadania co CKZ.

Nabywanie kompetencji ogólnych może odbywać się w postaci kursów prowadzonych przez publiczne i niepubliczne placówki kształcenia ustawicznego i centra kształcenia zawodowego, a turnusy dokształ- 
cania teoretycznego młodocianych mogą być organizowane przez publiczne i niepubliczne szkoły prowadzące kształcenie zawodowe oraz publiczne i niepubliczne centra kształcenia zawodowego.

Podmioty przyjmujące uczniów na praktyczną naukę zawodu odpowiadają za:

$\rightarrow$ zapewnienie właściwych warunków materialnych do realizacji PNZ (stanowisko pracy, sprzęt, odzież itp.);

$\rightarrow$ wyznaczenie instruktorów praktycznej nauki zawodu, opiekunów praktyk zawodowych lub nauczycieli praktycznej nauki zawodu (CKZ);

$\rightarrow$ zapewnienie przeszkolenia z zakresu regulaminu pracy i BHP, a także sporządzenie dokumentacji wypadkowej;

$\rightarrow$ współpracę z podmiotem organizującym kształcenie, w tym informowanie o ewentualnych naruszeniach regulaminu pracy przez ucznia/młodocianego pracownika.

Koszty ponoszone przez podmiot prowadzący praktyczną naukę zawodu podlegają refundacji na zasadach określonych przez Rozporządzenie. Za zabezpieczenie środków finansowych na ten cel odpowiada organ prowadzący szkoły. Refundacji podlegają: wynagrodzenie instruktorów praktycznej nauki zawodu (do wysokości minimalnej stawki wynagrodzenia nauczyciela kontraktowego), dodatek szkoleniowy dla nich oraz koszty odzieży i obuwia roboczego. Niezależnie od przyjętego modelu realizacji PNZ, katalog obowiązków szkoły w tym zakresie pozostaje niezmienny - składają się na niego następujące elementy:

$\rightarrow$ nadzór nad realizacją PNZ;

$\rightarrow$ współpraca z podmiotem realizującym PNZ;

$\rightarrow$ ubezpieczenie NNW, zwrot kosztów dojazdu, a w razie potrzeby bezpłatne zakwaterowanie i ryczałt na wyżywienie dla uczestników PNZ;

$\rightarrow$ akceptacja instruktorów praktycznej nauki zawodu, opiekunów praktyk zawodowych lub wyznaczenie nauczycieli praktycznej nauki zawodu;

$\rightarrow$ kalkulacja kosztów PNZ na potrzeby organu prowadzącego.

Warto zwrócić uwagę, że pracodawca w polskim systemie kształcenia zawodowego może występować w dwojakiej roli - organizatora kształcenia i zarazem podmiotu przyjmującego młodocianych pracow- 
ników lub też wyłącznie podmiotu przyjmującego uczniów na praktyczną naukę zawodu.

Tabela 4. Formy przygotowania zawodowego młodocianych pracowników ${ }^{31}$

\begin{tabular}{|c|c|c|}
\hline \multicolumn{2}{|r|}{ nauka zawodu } & \multirow{2}{*}{$\begin{array}{l}\text { przyuczenie do wykonywania } \\
\text { określonej pracy } \\
\text { od } 3 \text { do } 6 \text { miesięcy, } \\
\text { w przypadku pozostających } \\
\text { pod opieką OHP uczniów } \\
\text { gimnazjów może być } \\
\text { przedłużony do } 22 \text { miesięcy }\end{array}$} \\
\hline $\begin{array}{l}\text { maksymalny okres } \\
\text { trwania }\end{array}$ & do 36 miesięcy & \\
\hline zawody & $\begin{array}{l}\text { określone w klasyfikacji zawodów szkolnictwa } \\
\text { zawodowego lub zawodach odpowiadających } \\
\text { danemu rodzajowi rzemiosła }\end{array}$ & nie dotyczy \\
\hline $\begin{array}{l}\text { formy dokształce- } \\
\text { nia teoretycznego }\end{array}$ & $\begin{array}{l}\text { dokształcanie teoretyczne we własnym zakresie } \\
\text { lub w branżowej szkole I stopnia / na turnusach } \\
\text { dokształcania teoretycznego }{ }^{32}\end{array}$ & nie dotyczy \\
\hline wynagrodzenie & $\begin{array}{l}\text { w stosunku do przeciętnego wynagrodzenia } \\
\text { w gospodarce narodowej w poprzednim kwartale: } \\
\text { I rok - } \min .5 \% \text { * } \\
\text { II rok - } \min .6 \% \text { * } \\
\text { III rok }-\min .7 \% \text { * }\end{array}$ & $\begin{array}{l}\text { w stosunku do przeciętnego } \\
\text { wynagrodzenia } \\
\text { w gospodarce narodowej } \\
\text { w poprzednim kwartale: } \\
\text { min. } 4 \%\end{array}$ \\
\hline egzamin & $\begin{array}{l}\text { w przypadku rzemiosła: } \\
\text { egzamin kwalifikacyjny na tytuł czeladnika } \\
\text { przeprowadzany przez komisje egzaminacyjne izb } \\
\text { rzemieślniczych zgodnie z właściwymi przepisami } \\
\text { pozostali pracodawcy: } \\
\text { egzamin potwierdzający kwalifikację w zawodzie } \\
\text { na zasadach przewidzianych dla szkół publicznych } \\
\text { lub egzaminów eksternistycznych }\end{array}$ & $\begin{array}{l}\text { w przypadku rzemiosła: } \\
\text { egzamin przed komisją egza- } \\
\text { minacyjną izby rzemieślniczej, } \\
\text { na zasadach określonych przez } \\
\text { Związek Rzemiosła Polskiego } \\
\text { pozostali pracodawcy: } \\
\text { egzamin sprawdzający }\end{array}$ \\
\hline
\end{tabular}

* Stawki obowiązują od 1 września 2019 r.

Źródło: opracowanie własne na podstawie Rozporządzenie Rady Ministrów z dnia 28 maja

1996 r. w sprawie przygotowania zawodowego młodocianych i ich wynagradzania, wraz z późniejszymi zmianami (ostatnia z 16 sierpnia 2017 r.).

31 Rozporządzenie Rady Ministrów z dnia 28 maja 1996 r. w sprawie przygotowania zawodowego młodocianych i ich wynagradzania, wraz z późniejszymi zmianami (ostatnia z 16 sierpnia 2017 r.), Dz.U. 1996 nr 60 poz. 278.

32 Ustawa z dnia 22 listopada 2018 r. określa, że organizatorem turnusów dokształcania teoretycznego młodocianych mogą być publiczne i niepubliczne szkoły prowadzące kształcenie zawodowe oraz publiczne i niepubliczne centra kształcenia zawodowego. 
W ramach kształcenia młodocianych pracowników równolegle funkcjonują specyficzne uregulowania dotyczące przyjmowania młodocianych pracowników dla pracodawców niebędących rzemieślnikami oraz pracodawców-rzemieślników, których system szkolenia był rozwijany i nadzorowany przez izby rzemieślnicze. Pracodawcy przyjmujący młodocianych pracowników mogą ubiegać się bowiem o refundację kosztów wynagrodzenia i składek na ubezpieczenie społeczne ze środków Funduszu Pracy. Zwrot ma charakter pomocy de minimis, a w jego wypłacie pośredniczą wojewódzkie komendy Ochotniczych Hufców Pracy (OHP) ${ }^{33}$.

W tym kontekście warto wspomnieć o szczególnej roli, jaką OHP odgrywają w systemie kształcenia zawodowego. Historia tej organizacji sięga okresu przedwojennego, jej pierwowzorem była młodzieżowa organizacja paramilitarna - Junackie Hufce Pracy (JHP) - powołana we wrześniu $1936 \mathrm{r}$. Zadaniem JHP było przysposobienie wojskowe młodzieży, pomoc w zdobywaniu kwalifikacji zawodowych, edukacji ogólnej i wychowaniu obywatelskim. Organizacja została reaktywowana po wojnie, a po 1989 r. przeszła istotną reorganizację i utraciła swój paramilitarny charakter. Od 2004 r. jest to wyspecjalizowana państwowa jednostka administracji podporządkowana ministrowi właściwemu ds. pracy. Jako instytucja rynku pracy OHP są ukierunkowane na wspieranie młodzieży zagrożonej wykluczeniem społecznym i młodych bezrobotnych (do 25 r.ż.). W tym celu realizują liczne działania z zakresu poradnictwa i kształcenia zawodowego, a także pośrednictwa pracy.

OHP nie tylko pośredniczą w wypłacie refundacji z Funduszu Pracy dla pracodawców przyjmujących młodocianych pracowników, ale również same organizują PNZ dla swoich podopiecznych na zasadach przewidzianych dla młodocianych pracowników - zarówno w formie przyuczenia do wykonywania określonej pracy, jak i nauki zawodu. Praktyczne przygotowanie zawodowe w OHP może odbywać się w warsztatach szkoleniowych prowadzonych przez jednostki OHP lub u współpracujących z nimi zewnętrznych pracodawców. Oferta praktycznego przygotowania zawodowego w OHP obejmuje obecnie ponad 60 zawodów $^{34}$. pracownikom, Dz.U. 2014 poz. 865. 


\section{Wykształcenie zawodowe}

Wykształcenie zawodowe jest szeroko rozumianą kategorią, bowiem odnosi się nie tylko do typu szkoły, który to wykształcenie pozwala uzyskać, ale także do poziomu wykształcenia, zawodu czy kierunku kształcenia i umiejętności zawodowych zdobytych poprzez doświadczenie w wykonywaniu zawodu. Nasze analizy koncentrują się na systemie szkolnym. Absolwent obecnej branżowej szkoły I stopnia (wcześniej zasadniczej) ma wykształcenie zawodowe, ma je także absolwent technikum oraz inżynier, który ukończył szkołę wyższą. Mamy zatem do czynienia z wykształceniem zawodowym na poziomie branżowej szkoły I stopnia, średniej szkoły zawodowej oraz szkoły wyższej. Osobną kategorią pozostają zawody i ich nazwy, które także, na co wskazuje doświadczenie ostatnich lat, zmieniają się. Na uczelniach ukończenie niektórych kierunków może prowadzić do uzyskania tytułu inżyniera, który jest tytułem zawodowym. W systemie szkolnym, przynajmniej w chwili obecnej, szkoła oferuje naukę zawodów zebranych w klasyfikacji zawodów tzw. szkolnych ${ }^{35}$. Zbiór tych zawodów, ich nazwy i opisy zmieniają się, ale gros zawodów nauczanych jest w szkołach od lat, np. technik ekonomista, technik budownictwa, sprzedawca czy mechanik pojazdów samochodowych.

Jak zatem rozumieć wykształcenie zawodowe? Można przyjąć, że aktualnie wykształcenie zawodowe jest definiowane przez efekty edukacji uzyskane w wyniku kształcenia. Jednak ten punkt widzenia nie zawsze dominował. W latach 80. ubiegłego stulecia panował pogląd, że poziom wykształcenia nie powinien być utożsamiany z uzyskanymi kwalifikacjami, bowiem przygotowanie szkolne stanowi tylko wstęp do zdobywania rzeczywistych kwalifikacji, które osiąga się, pracując (Nowacki 1983). Jak zatem zorganizować proces kształcenia, aby absolwent nie tylko z powodzeniem ukończył szkołę kształcącą zawodowo, ale także uzyskał kwalifikacje, które pozwalają wykonywać powierzone mu zadania? Jest to istotne, bowiem absolwent szkoły, który zdał egzamin zawodowy, uzyskał równocześnie dyplom potwierdzający te kwalifikacje. W rzeczywistości stosunek między osiągniętym wykształceniem a postulowanymi w procesie nauczania kwalifikacjami jest bar- 
dzo złożony. Pierwsze zagadnienie dotyczy relacji między kształceniem ogólnokształcącym a zawodowym (liczba godzin kształcenia, sposób konstruowania programu nauczania przedmiotów ogólnokształcących i zawodowych, sposób nauczania tych grup przedmiotów), drugie - relacji między kształceniem zawodowym teoretycznym i praktycznym (podobnie jak poprzednio: liczba godzin, sposób konstruowania programu nauczania), trzecie - miejsca realizacji praktycznej nauki zawodu (szkoła, CKZ, przedsiębiorstwo). Osobnym zagadnieniem są zdolności uczniów, ich chęć do nauki i motywacje wyboru szkoły.

Nie ma np. jednoznacznej odpowiedzi na pytanie, kim dzisiaj na rynku pracy są technicy i dlaczego niektórzy z nich nie znajdują pracy w wyuczonym zawodzie. Jak wskazują badania, technicy nie posiadają wystarczających umiejętności praktycznych, jakich oczekują pracodawcy, trudno jest im także znaleźć pracę w wyuczonym zawodzie (Kocór i in. 2012; Drogosz-Zabłocka 2012). Możliwe, że są wypierani przez absolwentów studiów inżynierskich i licencjackich, a może przez absolwentów szkół zasadniczych zawodowych, którzy posiadają więcej umiejętności praktycznych. Być może jest jednak tak, że pracodawca oczekuje efektywnego wykonywania zadań zawodowych, np. takich, które narzuca mu uzyskany kontrakt lub zamówienie.

Przyjmując obecny punkt widzenia, że na wykształcenie zawodowe składają się efekty kształcenia w postaci wiedzy, umiejętności zawodowych oraz kompetencji personalnych i społecznych niezbędnych do wykonywania zawodu lub uzyskania kwalifikacji wyodrębnionych w zawodzie, trzeba zaznaczyć, że efekty te zostały zdefiniowane w wyniku badań i analiz jako dominujące. Nie obejmują one jednak, co trzeba podkreślić, całości wiedzy i umiejętności przypisanych do zawodu, a ściślej do kwalifikacji. Nasze analizy dotyczą wyłącznie wykształcenia uzyskiwanego $w$ systemie szkolnym.

W programach nauczania, które powstają na bazie efektów kształcenia zdefiniowanych w podstawach programowych kształcenia w zawodach, praktyczny wymiar kształcenia zawodowego zajmuje istotne miejsce. Dotyczy to szczególnie branżowych szkół I stopnia, ale także zreformowanych pięcioletnich techników. Czy szkoły radzą sobie z zadaniem konstruowania i realizowania programów nauczania? $\mathrm{Na}$ pewno tak, a rozwiązań szukają zwykle w tradycji, dotychczasowych dokumentach, wzorcowych programach nauczania i doświadczeniu. Od 2012 r. w proces tworzenia programów nauczania włączani są pra- 
codawcy (wcześniej też mogli w nim uczestniczyć, ale w różnym wymiarze i na różnych zasadach).

Kwalifikacje w zawodzie potwierdza egzamin zawodowy. Komisje egzaminacyjne funkcjonujące od kilkunastu lat wypełniają swoje zadania, przygotowując i przeprowadzając egzaminy. Jednak ich efekty, mimo ciągłego doskonalenia egzaminów i prób powiązania kształcenia z wymaganiami rynku pracy, nie zawsze znajdują uznanie wśród pracodawców, zaś same egzaminy zawodowe nie są powszechnie uznawane za prestiżowe i przydatne na rynku pracy. Dla wykształcenia zawodowego zmiany w tym zakresie powinny mieć priorytetowe znaczenie.

Przedstawione $w$ tym rozdziale przemiany w kształceniu zawodowym oraz jego efekty w postaci wykształcenia zawodowego pokazują sukcesy i porażki w tym zakresie, naświetlają także problemy, z jakimi przyszło się zmagać reformatorom. Można zaryzykować twierdzenie, że w kształceniu zawodowym ciągle zachodzą zmiany, niektóre z nich mają charakter trwały, inne efemeryczny. Perspektywa, z jakiej te przemiany obserwujemy, pozwala na stwierdzenie, że przygotowanie reform, ich wdrożenie i ocena wymagają pogłębionej refleksji i badań. 